WMJ (Warmadewa Medical Journal), Vol. 6 No. 1 Mei 2021, Hal. 7-12

\title{
Gastrointestinal Involvement in The Confirmed Covid-19 \\ Patients
}

\author{
Rachma Greta Perdana Putri ${ }^{1}$, Wulandari Berliani Putri ${ }^{2}$, Razmaeda Sarastry ${ }^{3}$ \\ ${ }^{1}$ Departement of Histology, Faculty of Medicine, Universitas Ahmad Dahlan, Yogyakarta, Indonesia \\ ${ }^{2}$ Ngemplak I Community Health Center, Regional Health Office, Sleman, Yogyakarta, Indonesia \\ ${ }^{3}$ Mother and Child Hospital Mutiara Bunda Salatiga, Central Java, Indonesia \\ Email ${ }^{1}$ :rachmagreta@med.uad.ac.id
}

\begin{abstract}
The current pandemic of Coronavirus disease 2019, or known as COVID-19, has been claimed as Public Health Emergency of International Concern by WHO on 30 January 2020. According to WHO, there were 47.362.304 confirmed cases and 1.211.986 deaths were reported due to COVID-19 and still counting. This article investigated the involvement of gastrointestinal symptoms in COVID-19 related to the pathogenesis, transmission, and severity of the disease. The data was collected by keyword searching through EBSCO, PubMed, Google scholar, and additional references from retrieved articles. This article analyzed studies investigating gastrointestinal symptoms in Covid-19. The studies found gastrointestinal symptoms in COVID-19 confirmed patients such as abdominal pain, diarrhea, nausea, vomiting, constipation, and melena. Two studies showed that COVID-19 patients with gastrointestinal symptoms tended to have more severe disease. ACE2, as the receptor of S protein, was found abundantly in intestinal enterocytes besides in the respiratory system. Enterocyte abnormality induces decreased absorption of $\mathrm{NA}^{+}$, water, and mucosal disaccharides. It leads to increased undigested mono and disaccharides, carbohydrates, fats, and protein into the colon. As a result, the colon is unable to absorb sufficient water, leading to diarrhea. Gastrointestinal symptoms are commonly found in patients with COVID-19, and the trend is increasing in the later stage of the epidemic. SARS-CoV-2 enters gastrointestinal epithelial cells and the feces of COVID-19 patients are potentially infectious. The virus also found in wastewater system and may cause water pollution. Hence, further studies investigating gastrointestinal symptoms and possibility of fecal oral transmission should be conducted.
\end{abstract}

Keywords : COVID-19, Novel coronavirus, SARS-CoV-2, GI symptoms, Gastrointestinal

\section{Abstrak \\ [Keterlibatan Gastrointestinal pada Pasien terkonfirmasi COVID-19]}

Pandemi penyakit coronavirus 2019 atau disebut COVID-19 dinyatakan sebagai kegawatdaruratan kesehatan publik oleh WHO pada 30 Januari 2020. Berdasarkan WHO, sebanyak 47.362.304 kasus terkonfirmasi dan 1.211.986 kematian dilaporkan dan jumlahnya masih terus meningkat. Review ini menguraikan keterlibatan sistem gastrointestinal pada pasien terkonfirmasi COVID-19 yang terkait dengan patogenesis, transmisi, dan keparahan penyakit. Data didapatkan dari pencarian artikel melalui EBSCO, PubMed, Google Scholar, dan sumber lain. Review ini menganalisis gejala gastrointestinal yang terjadi pada pasien COVID19. Gejala gastrointestinal dialami oleh pasien terkonfirmasi COVID-19 antara lain nyeri perut, diare, mual, muntah, konstipasi, dan melena. Dua penelitian menyebutkan bahwa pasien dengan gejala gastrointestinal memiliki tingkat keparahan penyakit yang lebih besar. ACE2 sebagai reseptor dari $S$ protein banyak ditemukan pada enterosit selain pada sistem respirasi. Abnormalitas enterosit mengurangi absorpsi $\mathrm{Na}+$, air, dan disakarida mukosa sehingga meningkatkan mono dan disakarida, lemak, protein yang tak tercerna. Hal tersebut menyebabkan ketidakmampuan absorpsi air sehingga terjadi diare. Gejala gastrointestinal banyak ditemukan pada pasien COVID-19 dan jumlahnya semakin meningkat. SARS-CoV-2 yang masuk melalui sel epitelial dan feses pada pasien COVID-19 berpotensi infeksius. Virus juga ditemukan pada sistem pembuangan dan dapat menyebabkan polusi air. Oleh karena itu perlu dilakukan penelitian lebih lanjut terkait gejala gastrointestinal dan kemungkinan transmisi fekal-oral.

Kata Kunci : COVID-19, Novel coronavirus, SARS-CoV-2, gejala GI, Gastrointestinal 


\section{INTRODUCTION}

The current pandemic of Coronavirus disease 2019 (COVID-19) had been claimed as Public Health Emergency of International Concern by WHO (World Health Organization) on 30 January 2020. This pandemic is an enormous burden to more than 200 affected countries. According to WHO, there 47.362.304 confirmed cases and 1.211.986 deaths reported due to COVID-19 and still counting. (1) The majority of studies on COVID-19 emphasizes respiratory illness. While during the spread of the virus, viral mutations may arise. In the infected areas outside Wuhan, there were some symptoms of the gastrointestinal tract in COVID-19 patients as novel features. ${ }^{(2,3)}$ Meanwhile, articles from China and America have reported gastrointestinal manifestations of COVID-19. Nausea, vomiting and diarrhea are the most common symptoms appeared. In Indonesia, a case report from Bogor also reported similar case. A woman came to the hospital with epigastric pain as the main symptom. Other complaints were shortness of breath, nausea, and vomiting. There was no history of GERD symptoms. Yet, she acknowledged that there were fever and dry cough two days before the admission. The digestive symptoms recovered after getting medication for digestive symptoms, while the respiratory problem still existed. ${ }^{(4)}$ This should be taken into consideration as it may threaten health professionals who work on COVID-19 patients without any respiratory symptoms when they first arrive to seek health care providers. This article pooled the studies that reported GI tract symptoms on COVID-19 patients. The data was collected by keyword searching through MEDLINE, EBSCO, PubMed, Google scholar, and additional references from retrieved articles. This article encompasses the analysis of gastrointestinal involvement and the severity in COVID-19, the pathogenic mechanism of SARS-CoV-2 in gastrointestinal tract, and the potential of fecal oral transmission through wastewater system.

\section{REVIEW METHOD}

The data was collected by keywords searching through EBSCO, PubMed, Google scholar, and additional references from retrieved articles.

\section{RESULT AND DISCUSSION}

\section{Gastrointestinal Involvement and The Severity in COVID-19}

Gastrointestinal symptoms in the confirmed COVID-19 patients have declared as abdominal pain, diarrhea, nausea, vomiting, constipation, and melena. ${ }^{(5)}$ The majority of COVID-19 clinical manifestations from 645 patients in Zhejiang, China were fever $(85.9 \%)$, cough $(68.4 \%)$, diarrhea $(7.9 \%)$, nausea, and vomiting $(3.8 \%){ }^{(6)}$ Further, still in Zhejiang, a study found that among 651 regis- tered patients, diarrhea was the most common GI symptom. ${ }^{(2)}$ Meanwhile, a study in California also reported gastrointestinal symptoms in $31.9 \%$ of the cases. Loss of appetite $(22.3 \%)$ was the most common gastrointestinal symptoms. ${ }^{(7)}$ In the first case of COVID-19 in Washington, a man who had traveled from Wuhan, before his admission to hospital, had nausea and vomiting complaint for two days alongside with his respiratory illness symptoms. He also suffered from abdominal discomfort and underwent a stool sample examination confirming him to be positive for 2019-nCoV (SARS-CoV-2). ${ }^{(8)}$

A study from 73 COVID-19 patients which had GI bleeding showed no anomaly in the stomach, duodenum, colon, and rectum by endoscopy and H\&E staining. ${ }^{(9,10)}$ However, there was damage in the esophagus seen at endoscopy. ${ }^{(9)}$ Staining of lamina propria of the stomach, duodenum, and rectum, innumerable infiltrating plasma cell and lymphocytes with interstitial edema were visible. Gross appearance of the intestine showed segmental dilatation and stenosis from an autopsy, and segmental wall swelling was seen in abdominal CT-scan in other COVID-19 cases. Additionally, intracellular staining of viral nucleocapsid protein was detected in gastric, duodenal, and rectal epithelia. ${ }^{(9-11)}$

The correlation of SARS-CoV-2 in gastrointestinal has been elucidated in a study conducted using gut organoids. Human small intestinal organoid (hSIOs) from primary gut epithelial stem cells grown under 4 different culture conditions. SARS-CoV-2 productively infected hSIOs as assessed by qRT-PCR method. Under EXP medium, enterocyte progenitor becomes the place of viral replication. In the different hSIOs, SARS-CoV-2 titer remained stable at 60 hours after infection. The lysed of hSIOs contained a considerable amount of infectious virus signifying that virus was secreted apically. ${ }^{(12)}$ It is possible that SARS-CoV-2 could infect enterocytes due to the receptor availability.

Nevertheless, the severity of SARS-Co-V infection associated with digestive symptoms is still inconclusive. A descriptive, cross-sectional, multicenter study on 240 patients in the case of COVID19 showed that digestive symptoms were related to worse outcomes. It showed that $60 \%$ of patients without digestive symptoms recovered and were discharged, while only $34.3 \%$ of the patients with digestive symptoms recovered. ${ }^{(13)}$ In addition, Huang et al. reported that the number of digestive symptoms, especially anorexia and abdominal pain, was higher significantly in ICU patients than in nonICU patients. ${ }^{\text {(14) }}$

In contrary to that, Fang et al. found that $15.1 \%$ or 46 of 305 patients were critically ill. About $85 \%$ (17/20) of those critical cases had gastrointestinal symptoms and $44.7 \%(17 / 38)$ of them had diarrhea. The results were not statistically different from those of noncritical cases, where gastro- 
intestinal symptoms in non-severe patients accounted for $78.5 \%$, of which $50.2 \%$ had diarrhea (13). In accordance, a study by Guan et al. reported no difference in the proportion of gastrointestinal symptoms between severe and non-severe cases. ${ }^{(15)}$

However, it is difficult to evaluate whether the digestive symptoms are caused by SARS-CoV -2 infection or due to other secondary infections in critically ill patients. Gastrointestinal mucosal cell injury due to long-term hypoxemia, cell necrosis from tissue hypoxia is commonly found in critical patients. Furthermore, treatments including corticosteroids and NSAIDs, and the physiological stress in patients with severe illness could have injured the mucosa of the digestive tract, thus making it difficult to trace the causal factor.

\section{The Pathogenic Mechanism of SARS-CoV-2 in Gastrointestinal Tract}

A study conducted by $\mathrm{Li}$ et al (2003), suggested that ACE2 (Angiotensin-Converting Enzyme 2) could be modulated by the $\mathrm{S} 1$ domain of SARS-CoV. Spike protein-mediated fusion with $\mathrm{S}$ protein-expressing cells can develop viral replication in a cell line. It clarifies that ACE2 is a fundamental receptor for SARS-CoV. ${ }^{(16)}$ There are many similarities between SARS-CoV-2 and the original SARS-CoV. By using computer modeling, the spike protein of SARS-CoV-2 and SARS-CoV is almost identical to 3-D structures in the receptor-binding domain. They have a solid binding affinity to human ACE2. ${ }^{(6)}$ Coronavirus has to deliver its nucleocapsid into the host cell to initiate infection. Viral entry relies on the fusion between the envelopes and the membrane of host cell as the function of the spike protein. Spike protein of the virus needs to be cleaved and activated by host protease including cathepsin L, TMPRSS2 (Transmembrane Protease Serine 2), TMPRSS4, TMPRSS11A, TMPRSS11D, TMPRSS11E. After binding to the surface receptor of the cell, TMPRSS2 cleaves the ACE2 afterward to activate $S$ protein. It facilitates viral entry to the host cell. ${ }^{(17-19)}$ When the virus enters the host cell, it will be seized by Antigen Presenting Cell (APC) and sent to T-helper to activate immune response. ${ }^{(18)}$ On the other hand, after the fusion of the host membrane, pseudovirion enters cells through endocytosis. Phosphatidylinositol-3, 5-bisphosphate (PI $(3,5)$ P2) is an important component for endocytosis which regulates the dynamics of early endosomes to late endosomes. Cathepsin L which has a role in viral entry is essential for priming SARS-CoV-2 S protein in the lysosome. ${ }^{(19)}$

Spike protein consists of two subunits (S1 and S2) after being degraded by protease. S1 contains the receptor-binding domain (RBD) and is responsible for the recognition and binding to the host cell receptor, while S2 is a typical of class I viral fusion protein. In order to infect new host spe- cies, the virus must adapt to the receptor of the house either by mutation or recombination of the virus. ${ }^{(20,21)}$ Once the virus has reached an initial binding to the receptor, it will lead to S1 dissociation and help S2 to prepare membrane fusion. Thus, the nucleocapsid will be delivered. The receptorbinding domain of SARS-CoV-2 specifically recognized the ACE2 receptor. Residue in SARS-CoV-2 $\mathrm{RBD}$ that responsible for cross-species transmission are $493,501,455,486$, and $494 .^{(22)}$ The mutation of RBD residue, influence the binding affinity of RBD and human ACE2. For example, the replacement of SARS-CoV-2 RBD N501 with T487 strengthens ACE2 binding significantly. ${ }^{(23)}$

Further, as the gastrointestinal tract filled with the amount of ACE2, it is possible that the symptoms of COVID-19 related to gastrointestinal symptoms. The previous study stated that in epithelial cells of the ileum, the expression of ACE2 was high in absorptive enterocytes, and low in progenitor absorptive cells. In the colon, the expression of ACE2 was found to be high in enterocytes, and low expression was found in immature enterocytes. ${ }^{(24)}$ ACE2 expression was primarily mapped to the luminal surface of differentiated small intestinal epithelial cells, while lower ACE2 expression was observed in crypt cells and the colon and, in contrast, another article was found to have high ACE2 expression in the colon ${ }^{.(25,26)}$ Enterocyte performs as a barrier. It processes antigen through two pathways, including major pathway by using lysosome to degrade antigen and minor trans-cytolytic pathway by releasing the antigen into interstitial space. Enterocytes can present as antigen-presenting cells and also have absorptive function. The absorptive enterocyte makes up $>80 \%$ of all small intestinal epithelial cells. Macromolecule transports through enterocyte via transcellular transport and efficiently transports into the enterocyte by receptor-mediated endocytosis. ${ }^{(27)}$ Abnormality of enterocytes, for example the destruction of enterocyte caused by rotavirus, can cause malabsorption. It leads to a decrease in the absorption of $\mathrm{NA}^{+}$, water, and mucosal disaccharidases. As a result, the colon will be unable to absorb sufficient water, leading to diarrhea. Villus enterocyte is mature and covers the villi that are differentiated into digestive and absorptive functions. Absorptive enterocyte synthesizes disaccharidases, peptidases, and other enzymes that are expressed on the apical surface that carries out their digestive function. ${ }^{(28)}$

ACE2 acts as a key regulator of processes in the human body, such as dietary amino acid homeostasis, innate immunity, gut microbial ecology, and transmissible susceptibility to colitis. ${ }^{(25)}$ ACE2 is required for the expression of this transporter on the luminal surface of intestinal epithelial cells. The pattern of coronavirus entrance is through the apical site of the polarized epithelial cells and it can be released through either apical or basolateral. The apical release will release the virus to the gut lumen 
and close by the target cell, while basolateral release will send the virus to the blood and lymph vessel. ${ }^{(29)}$ However, the role of enterocytes and ACE2 receptors in the pathogenesis of SARS-CoV-2 still needs to be investigated.

\section{Possibility of Fecal-Oral Transmission}

From a previous case report, in the first case of COVID-19 in the United States, some samples of patients were collected to detect the RNA virus of SARS-CoV-2. The specimens taken were nasopharyngeal swab, oropharyngeal swab, serum, urine, and stool. On the 7th day of the illness, the stool was tested for SARS-CoV-2 and the result was positive for SARS-CoV-2 (Ct value, 36 to 38$).{ }^{(8)}$ Another investigation from 73 patients infected with SARS-CoV-2 showed that the stool was tested positive for SARS-CoV-2 RNA. The duration for stool to show positive results ranged from 1-12 days and might be longer until 47 days from another research. Furthermore, $17(23.29 \%)$ patients continued to have positive results in stool after representing negative results in respiratory samples. ${ }^{(30,31)}$

Viral host receptor ACE2 stained positive mainly in the cytoplasm of gastrointestinal epithelial cells. The positive staining of ACE2 and SARSCoV-2 was also noticed in gastrointestinal epithelium from patients who were tested positive for SARS-CoV-2 RNA in feces. ${ }^{(10)}$ In fluid specimens, such as sputum, feces, and serum, SARS-CoV can be detected for 96 hours. $^{(32)}$ J.Kim (2020) was trying to isolate the SARS-CoV-2 virus from SARS-CoV2 positive serum, urine, or stool sample. They were inoculated the virus to CACO-2 cells and the cells were cultured for 5 days after primary inoculation. Later, secondary inoculation was presented nevertheless, the virus could not be isolated from the sample even in the stool or serum samples contain the highest RNA concentration. It may cause by the low level of the viral load. ${ }^{(33)}$ Some studies observed viral load in stool samples, informed that the peak of viral load found two until four weeks after the onset of the symptoms. ${ }^{(34,35)}$ The peak load of the viral in the stool is $1.1 \times 10^{8}$ copies $/ \mathrm{ml}$ and becomes the lowest compare to viral load in sputum and nasopharyngeal. ${ }^{(36)}$ In children, viral loads from anal swabs compared to throat specimens were no difference. ${ }^{(37)}$ Although there was viral RNA detected in feces, the infectivity of the viral could not be proven yet. The unsuccessful viral isolation might be caused by the lower of viral load or the isolation specimen was not at the peak of the viral load.

As the viral RNA found in the stool, its spreading into wastewater should be surveilled. The finding of SARS-CoV-2 RNA in influent water and wastewater has been reported worldwide. In Spain, $83 \%$ of influent samples and $11 \%$ secondary treated water samples were tested positive for SARS-CoV-2 RT-qPCR target. The studies have been reported the finding of SARS-CoV-2 RNA in wastewater in The Netherland, France, USA, Italia, and Australia. ${ }^{(38-40)}$
The virus contained in feces may run into dilution and the viral load decreased approximately $2.5 \times 10^{3}$ copies/mL. ${ }^{(41)}$ In the urban areas in Indonesia, about $1 \%$ of the wastewater collected and treated safely, yet in the rural areas, wastewater is not collected and treated in 2016. They used septic tanks which were located less than 10 meters from community wells. ${ }^{(42)}$ This may cause water pollution according to the fecal-oral transmission for viruses or bacterial diseases. The fecal-oral transmission of the SARSCoV-2 virus should be taken into consideration, although the level of viral load in wastewater was low. There were no studies yet about the infectivity of SARS-CoV-2 that was isolated from the stool and wastewater.

\section{CONCLUSION}

Health care providers should pay attention to patients who have complaints of respiratory illness or gastrointestinal symptoms in this pandemic era. The symptoms of COVID-19 suspects may not only appear in the form of respiratory illness, but also gastrointestinal symptoms, and the trend is increasing in the later stage of the epidemic. SARSCoV-2 enters gastrointestinal epithelial cells, and the feces of COVID-19 patients are potentially infectious. Neglected environmental hygiene including wastewater system and fecal oral hygiene should be considered as mode of transmission for SARS-CoV-2.

\section{REFERENCES}

1. WHO. WHO Corona Virus Disease Dashboard [Internet]. 2020. Available from: https://covid19. who.int

2. Jin X, Lian JS, Hu JH, Gao J, Zheng L, Zhang YM, et al. Epidemiological, clinical and virological characteristics of 74 cases of coronavirus-infected disease 2019 (COVID19) with gastrointestinal symptoms. Gut. 2020;0:1-8.

3. Li G, Fan Y, Lai Y, Han T, Li Z, Zhou P, et al. Coronavirus infections and immune responses. J Med Virol. 2020;92(4):424-32.

4. Azwar MK, Kirana F, Kurniawan A, Handayani S, Setiati S. Gastrointestinal Presentation in COVID-19 in Indonesia: A Case Report. Acta Med Indones. 2020;52 (1):63-7.

5. Hormati A, Shahhamzeh A, Afifian M, Khodadust F, Ahmadpour S. Can COVID19 present unusual GI symptoms? J Microbiol Immunol Infect [Internet]. 2020;(03):19 -20. Available from: https:// doi.org/10.1016/j.jmii.2020.03.020

6. Zhang H, Penninger JM, Li Y, Zhong N, Slutsky AS. Angiotensin-converting enzyme 2 (ACE2) as a SARS-CoV-2 receptor: 
molecular mechanisms and potential therapeutic target. Intensive Care Med [Internet]. 2020;46(4):586-90. Available from: https:// doi.org/10.1007/s00134-020-05985-9

7. Cholankeril G, Podboy A, Aivaliotis VI, Tarlow B, Pham EA, Spencer S, et al. High Prevalence of Concurrent Gastrointestinal Manifestations in Patients with SARS-CoV2: Early Experience from California. Gastroenterology [Internet]. 2020;1-12. Available from: http://www.ncbi.nlm.nih.gov/ pubmed/32283101

8. Lofy KH, Wiesman J, Bruce H, Spitters C, Ericson K, Wilkerson S, et al. First Case of 2019 Novel Coronavirus in the United States. N Engl J Med. 2020;382(10):92936.

9. Su S, Shen J, Zhu L, Qiu Y, He J, Tan J, et al. Involvement of digestive system in COVID-19: manifestations, pathology , management and challenges. 2020;(April):1 -12 .

10. Xiao F, Tang M, Zheng X, Liu Y, Li X, Shan H. Evidence for Gastrointestinal Infection of SARS-CoV-2. Gastroenterology. 2020;(158):1831-3.

11. Guo Y, Hu X, Yu F, Chen J, Zheng W, Liu $\mathrm{J}$, et al. Abdomen CT findings in a COVID19 patient with intestinal symptoms and possibly false negative RT-PCR before initial discharge. 2020;10(5):1158-61.

12. Lamers MM, Beumer J, Der VJ Van, Knoops K, Puschhof J, Breugem TI, et al. SARS-CoV-2 productively infects human gut enterocytes. Science (80- ). 2020; (369):50-4.

13. Pan L, Mu M, Yang P, Sun Y, Wang R, Yan J, et al. Clinical Characteristics of COVID19 Patients With Digestive Symptoms in Hubei, China | PracticeUpdate. Am J Gastroenterol [Internet]. 2020;115(May):76673. Available from: https:// www.practiceupdate.com/content/clinicalcharacteristics-of-covid-19-patients-withdigestive-symptoms-in-hubei-china/98000

14. Huang C, Wang Y, Li X, Ren L, Zhao J, Hu $\mathrm{Y}$, et al. Clinical features of patients infected with 2019 novel coronavirus in Wuhan, China. Lancet. 2020;395(10223):497-506.

15. Tang X, Du R, Wang R, Cao T, Guan L, Yang C, et al. Comparison of Hospitalized Patients with Acute Respiratory Distress Syndrome Caused by COVID-19 and H1N1. Chest [Internet]. 2020;(April):1-11. Available from: https://doi.org/10.1016/ j.chest.2020.03.032

16. Li W, Moore MJ, Vasilieva N, Sui J. Angiotensin-converting enzyme 2 is a functional receptor for the SARS coronavirus. Nature. 2003;426(NOVEMBER):450-3.

17. Astuti I, Ysrafil. Severe Acute Respiratory Syndrome Coronavirus 2 (SARS-CoV-2):
An overview of viral structure and host response. Diabetes Metab Syndr Clin Res Rev. 2020;(April).

18. Rabi FA, Al Zoubi MS, Al-Nasser AD, Kasasbeh GA, Salameh DM. Sars-cov-2 and coronavirus disease 2019: What we know so far. Pathogens. 2020;9(3):1-14.

19. Ou X, Liu Y, Lei X, Li P, Mi D, Ren L, et al. Characterization of spike glycoprotein of SARS-CoV-2 on virus entry and its immune cross-reactivity with SARS-CoV. Nat Commun [Internet]. 2019;(2020). Available from: http://dx.doi.org/10.1038/s41467-02015562-9

20. Lan J, Ge J, Yu J, Shan S, Zhou H, Fan S, et al. Structure of the SARS-CoV-2 spike receptor-binding domain bound to the ACE2 receptor. Nature. 2020;

21. Belouzard S, Millet JK, Licitra BN, Whittaker GR. Mechanisms of Coronavirus Cell Entry Mediated by the Viral Spike Protein. Viruses. 2012;4:1011-33.

22. Wan Y, Shang J, Graham R, Baric RS, Li F. Receptor Recognition by the Novel Coronavirus from Wuhan: an Analysis Based on Decade-Long Structural Studies of SARS Coronavirus. J Virol. 2020;94(7):1-9.

23. Yi C, Sun X, Ye J, Ding L, Liu M, Yang Z, et al. Key residues of the receptor binding motif in the spike protein of SARS-CoV-2 that interact with ACE2 and neutralizing antibodies. Cell Mol Immunol [Internet]. 2020;(April). Available from: http:// dx.doi.org/10.1038/s41423-020-0458-Z

24. Zhang H, Kang Z, Gong H, Xu D, Wang J, $\mathrm{Li} \mathrm{Z}$, et al. The digestive system is a potential route of 2019-nCov infection: a bioinformatics analysis based on single-cell transcriptomes. 2020;

25. Hashimoto T, Perlot T, Rehman A, Trichereau J, Ishiguro $\mathrm{H}$, Paolino $\mathrm{M}$, et al. ACE2 links amino acid malnutrition to microbial ecology and intestinal inflammation. Nature. 2012;4-10.

26. Zhang H, Kang Z, Gong H, Xu D, Wang J, $\mathrm{Li} Z$, et al. The digestive system is a potential route of 2019-nCov infection: a bioinformatics analysis based on single-cell transcriptomes.

bioRxiv. 2020;2020.01.30.927806.

27. Snoeck V, Goddeeris B, Cox E. The role of enterocytes in the intestinal barrier function and antigen uptake. Microbes Infect. 2005;7:997-1004.

28. Ramig RF. Pathogenesis of Intestinal and Systemic Rotavirus Infection. J Virol. 2004;78(19):10213-20.

29. Cong Y, Ren X. Coronavirus entry and release in polarized epithelial cells : a review. rev Med Virol. 2014;24:308-15.

30. Xiao F, Tang M, Xiaobin Z, Liu Y, Li X, Shan H. Evidence for Gastrointestinal Infec- 
tion of SARS-CoV-2. Gastroenterology. 2020;(158):1831-3.

31. Wu Y, Guo C, Tang L, Hong Z, Zhou J, Dong $X$, et al. Prolonged presence of SARSCoV-2 viral RNA in faecal samples. Lancet Gastroenterol Hepatol [Internet]. 2020;5 (5):434-5. Available from: http:// dx.doi.org/10.1016/S2468-1253(20)30083-2

32. Wolff MH, Sattar SA, Adegbunrin O, Tetro J. Environmental survival and microbicide inactivation of coronaviruses. Coronaviruses with Spec Emphas First Insights Concern SARS. 2005;201-12.

33. Kim J, Man H, Jung E, Jun H, Yoon Y, Lee $\mathrm{N}$, et al. Detection and Isolation of SARSCoV-2 in Serum, Urine, and Stool Specimens of COVID-19 Patients from the Republic of Korea. Osong Public Heal Res Perspect. 2020;11(3):112-7.

34. Walsh KA, Jordan K, Clyne B, Rohde D, Drummond L, Byrne P, et al. SARS-CoV-2 detection, viral load and infectivity over the course of an infection. J Infect [Internet]. 2020;8:29. Available from: https:// doi.org/10.1016/j.jinf.2020.06.067

35. Zheng S, Fan J, Yu F, Feng B, Lou B, Zou $\mathrm{Q}$, et al. Viral load dynamics and disease severity in patients infected with SARSCoV-2 in Zhejiang province, China, January-March 2020 : retrospective cohort study. 2020;(March):1-8.

36. Tan W, Lu Y, Zhang J, Wang J, Dan Y, Tan Z. Viral Kinetics and Antibody Responses in Patients with COVID-19. 2020;

37. Yuan C, Zhu H, Yang Y, Cai X, Xiang F. Viral loads in throat and anal swabs in children infected with SARS-CoV-2. Emerg Microbes Infect. 2020;9:1232-7.

38. Allende A, Gloria S. SARS-CoV-2 RNA in wastewater anticipated COVID-19 occurrence in a low prevalence area. 2020;181.

39. La G, Iaconelli M, Mancini P, Bonanno G, Veneri C, Bonadonna L, et al. First detection of SARS-CoV-2 in untreated wastewaters in Italy. Sci Total Environ [Internet]. 2020;736:139652. Available from: https://doi.org/10.1016/ j.scitotenv.2020.139652

40. Ahmed W, Angel N, Edson J, Bibby K, Bivins A, Brien JWO, et al. First confirmed detection of SARS-CoV-2 in untreated wastewater in Australia: A proof of concept for the wastewater surveillance of COVID19 in the community. Sci Total Environ [Internet]. 2020;728:138764. Available from: https://doi.org/10.1016/ j.scitotenv.2020.138764

41. Foladori P, Cutrupi F, Segata N, Manara S, Pinto F, Malpei F, et al. SARS-CoV-2 from faeces to wastewater treatment: What do we know? A review. Sci Total Environ. 2020;743:140444.

42. Marleni NNN, Raspati GS. A Critical Review of Wastewater Resource Recovery Implementation in Indonesia. J Civ Eng Forum. 2020;6(1):89-102. 